\title{
Identification of GIRK2-4 subunits in human esophageal smooth muscle cells
}

\author{
QIANG LU $^{1 *}$, LI GONG $^{2 *}$, HUI XU ${ }^{3 *}$, TAO ZHANG $^{1}$, XIAOLONG YAN $^{1}$, \\ JINBO ZHAO $^{1}$, ZHIPEI ZHANG ${ }^{1}$, YUNJIE WANG ${ }^{1}$ and YONG HAN ${ }^{1}$
}

Departments of ${ }^{1}$ Thoracic Surgery and ${ }^{2}$ Pathology, Tangdu Hospital, The Fourth Military Medical University, Xi'an 710038; ${ }^{3}$ Institute of Neuroscience, The Fourth Military Medical University, Xi'an 710032, P.R. China

Received February 18, 2011; Accepted May 24, 2011

DOI: $10.3892 / \mathrm{mmr} .2011 .499$

\begin{abstract}
Acetylcholine (ACh) secreted from the vagus nerve contributes to the physiological and pathological regulation of the contraction and relaxation of human esophageal smooth muscle. Expression of acetylcholine-sensitive $G$ protein-activated inwardly rectifying potassium channels (GIRKs) occurs widely in the heart, nervous system and gastrointestine, but the role of GIRKs in the esophagus remains unclear. In the present study, expression of the GIRK1-4 subunits in mRNA and total protein was examined in human esophageal smooth muscle cells (SMCs) by reverse transcription polymerase chain reaction (RT-PCR) and Western blotting. mRNA and protein expression of the GIRK2-4 subunits was detected in human esophageal longitudinal muscle (LM) and circular muscle (CM) cells. However, GIRK1 mRNA and protein were not observed in either the esophageal LM or CM. This study is the first to identify the expression of GIRK2-4 subunits in human esophageal SMCs.
\end{abstract}

\section{Introduction}

$\mathrm{G}$ protein-activated inwardly rectifying $\mathrm{K}^{+}(\mathrm{GIRK})$ channels are members of a family of inward-rectifier $\mathrm{K}^{+}$(Kir) channels that includes 7 subfamilies $(1,2)$. GIRK channels play a crucial role in the inhibitory regulation of neuronal excitability in most brain regions and of the heart rate through the activation of various $\mathrm{G}$ protein coupled receptors, such as opioid, cannabinoid and D2 dopamine receptors $(3,4)$. In the heart, GIRK channels, previously named muscarinic $\mathrm{K}^{+}$channels, are activated by $\mathrm{M} 2$ muscarinic and $\mathrm{A} 1$ adenosine receptors, which

Correspondence to: Professor Yong Han and Professor Yunjie Wang, Department of Thoracic Surgery, Tangdu Hospital, The Fourth Military Medical University, Xi'an 710038, P.R. China

E-mail: han-yong@live.cn; xubz@fmmu.edu.cn

*Contributed equally

Key words: esophageal, smooth muscle cells, human, G proteinactivated inwardly rectifying potassium channels, acetylcholine are coupled to pertussis toxin-sensitive $\mathrm{G}$ proteins, the $\mathrm{Gi} / \mathrm{o}$ protein family (5). In the central nervous system (CNS), GIRK channels are activated by various $\mathrm{Gi} / \mathrm{o}$-protein-coupled receptors (Gi/oPCRs), such as a2 adrenergic and $\gamma$-aminobutyric acid type B $(3,4)$. In mammals, 4 GIRK channel subunits have been identified. Neuronal GIRK channels are predominantly heteromultimers comprising of GIRK1 and 2 subunits in most brain regions or homomultimers comprising of GIRK2 subunits in the substantia nigra and ventral tegmental region, whereas atrial GIRK channels are heteromultimers comprising of GIRK1 and 4 subunits $(3,6)$. Ablation of GIRK4 resulted in the functional elimination of $I_{K, \text { Ach }}(7)$. In the stomach, small bowel and proximal colon, GIRKs were encoded by GIRK1 and 2 (8). The existence of GIRK channels in esophageal smooth muscle cells (SMCs) as well as the roles of GIRKs in the contraction of esophageal SMCs remain to be determined. Acetylcholine (ACh) secreted from the vagus nerve modulates the contractility of the esophageal SMCs and regulates the esophageal SMC autorhythmicity via a mixed M2/M3 receptor $(9,10)$.

To investigate whether GIRK channels are expressed in the tissue of esophageal SMCs, and whether the expression of GIRK subunits differs between the longitudinal muscle (LM) and circular muscle (CM) of the esophagus, the expression of GIRK1-4 subunit mRNAs and protein was examined in human esophageal SMCs.

\section{Materials and methods}

Preparation of tissue specimens and esophageal SMC cultures. Tissues were obtained from a disease-free region of the midportion of the distal third of the esophagus obtained from 18 esophageal cancer patients aged between 35 and 65 years $(52.5 \pm 4.5, \mathrm{n}=18)$. Esophageal manometry, 24-h pH monitoring and esophagoscopy were performed to exclude esophagitis in all of the patients. The patients received no treatment such as radiation or chemotherapy prior to surgery. Permission for use of all specimens in this study was obtained from each patient. Each patient signed informed consent forms for sample collection. The study was approved by the Ethics Committee of the Fourth Military Medical University and the investigation conformed to the principles outlined in the Declaration of Helsinki. 
Table I. PCR primers.

\begin{tabular}{|c|c|c|c|c|c|}
\hline Gene & Accession no. & $\begin{array}{l}\text { Primer pair sequence } \\
\text { Sense/antisense }\end{array}$ & $\begin{array}{l}\text { Product size } \\
\quad \text { (bp) }\end{array}$ & $\begin{array}{l}\text { Location } \\
\left({ }^{\circ} \mathrm{C}\right)\end{array}$ & $\mathrm{Tm}$ \\
\hline GIRK1 & NM_002239 & $\begin{array}{l}\text { 5'-CGGTAACTACACGCCTTGC-3' } \\
\text { 5'-GTCTGCCGAGATTTGAGC-3' }\end{array}$ & 363 & 546-908 & 55.1 \\
\hline GIRK2 & NM_002240 & $\begin{array}{l}\text { 5'-CCCTCCTGGACTCC'T'T-3' } \\
\text { 5'-CCСTCT'GGCATTTATCT-3' }\end{array}$ & 122 & $379-500$ & 50.0 \\
\hline GIRK3 & NM_00498 & $\begin{array}{l}\text { 5'-CGCCTCAGCCTGTTG'TCT-3' } \\
\text { 5'-TGCCCGTAGCCGATGGTGGT-3' }\end{array}$ & 203 & $172-374$ & 58.3 \\
\hline GIRK4 & NM_000890 & $\begin{array}{l}\text { 5'-CACCTGGCTGTTCTTCGG-3' } \\
\text { 5'-GAGATGACTGCGTTGTTGG-3' }\end{array}$ & 330 & $296-625$ & 52.8 \\
\hline GAPDH & NM_002046 & $\begin{array}{l}\text { 5'-GGATTTGGTCGTATTGGG-3' } \\
\text { 5'-GATGATCTTGAGGCTGTTGTC-3' }\end{array}$ & 414 & $130-543$ & 53.5 \\
\hline
\end{tabular}

Primers were designed based on human gene sequences. Tm, temperature.

Histopathological analysis. Histopathological analysis was carried out on the Hematoxylin eosin (H\&E)- and immunohistochemistry-stained tissue slides in a blinded manner.

Immunostaining was carried out using a streptavidinlabeled peroxidase (S-P) kit (KIT9730) according to the manufacturer's instructions. The primary antibodies used in this study included those against epithelial membrane antigen (EMA), cytokeratin (CK), high-MW-CK, desmin, nerve specificity enolase (NSE), smooth muscle actin (SM-actin), vimentin, CD34, S-100 protein and CD117. The reagents used for immunostaining were supplied by Maxim Biotechnology Corporation Limited (Fuzhou, China).

RNA isolation and RT-PCR. Total RNA was extracted from the LM and CM groups of SMCs using a TRIzol kit (Invitrogen, Carlsbad, CA, USA) and acid guanidinium thiocyanate-phenol-chloroform extraction.

Total RNAs $(4 \mu \mathrm{g})$ were used to generate the first strand cDNA by reverse transcription (Invitrogen) according to the manufacturer's instructions. cDNA reaction mixture $(3 \mu \mathrm{l})$ was used in each polymerase chain reaction (PCR). PCR was performed in a $50 \mu 1$ reaction containing PCR buffer, $2 \mathrm{mM} \mathrm{MgCl}_{2}, 200 \mu \mathrm{M}$ dNTPs, $0.1 \mathrm{nM}$ of each primer, and 2 units of Taq DNA polymerase (Qiagen, Valencia, CA, USA). denaturation $\left(33\right.$ cycles; $\left.94^{\circ} \mathrm{C}, 30 \mathrm{sec}\right)$ annealing $\left(55-65^{\circ} \mathrm{C}\right.$, $30 \mathrm{sec})$, and extension $\left(72^{\circ} \mathrm{C}, 60 \mathrm{sec}\right)$ were conducted in a PCR thermal cycler (MJ PTC100, USA). Table I shows the primers for human GIRK1-4. PCR primers for GAPDH were used to confirm fidelity of the PCR reaction and to detect genomic DNA contamination.

The PCR products were then visualized by ultraviolet illumination after electrophoresis on $1 \%$ agarose-TAE $[10 \mathrm{mM}$ tris ( $\mathrm{pH} 7.5), 5.7 \%$ glacial acetic acid and $1 \mathrm{mM}$ EDTA] gels containing $0.5 \mu \mathrm{g} / \mathrm{ml}$ ethidium bromide. Gel images were then taken by a multianalyzer (Bio-Rad, Hercules, CA, USA). GAPDH was used as the internal control.

Western blotting. To detect GIRK subunit proteins, SMCs were rinsed with cold PBS. SMCs were washed in PBS and homogenized (Brinkmann Polytron) in $10 \mathrm{mM}$ HEPES buffer (pH 7.0) containing $1 \mathrm{mM}$ dithiothreitol and mini complete protease inhibitor cocktail tablets (1 tablet/25 $\mathrm{ml}$ buffer, Boehringer Mannheim, IN, USA).

Crude protein homogenates were denatured by boiling for $15 \mathrm{~min}$ in sodium dodecyl sulfate-polyacrylamide gel electrophoresis (SDS-PAGE) buffer. The extract was centrifuged at $12,000 \mathrm{x}$ g for $20 \mathrm{~min}$. Bradford protein assay reagent (Biocolor Bioscience, Shanghai, Inc., China) was used to determine the protein concentration of the samples. Samples were resolved by SDS-PAGE on a $12 \%$ gel and transferred onto a polyvinylidene difluoride membrane. The membranes were incubated in PBS buffer containing 5\% non-fat dry milk for $1 \mathrm{~h}$ at room temperature in order to block non-specific binding. After washing 3 times in PBS, the blots were incubated with primary antibodies in PBS solution containing $0.1 \% \mathrm{BSA}$ at $4^{\circ} \mathrm{C}$ overnight. The primary antibodies used were: anti-GIRK1 (1:600), anti-GIRK2 (1:600), anti-GIRK3 (1:600), anti-GIRK4 (1:600) (Santa Cruz, CA, USA) and anti-GADPH (1:300) (Bioss, Shanghai, China). The membranes were washed with PBS containing $0.05 \%$ Tween-20. The appropriate secondary antibody was used for each primary antibody and a signal was developed using Immobilon Western Chemiluminescent HRP substrate (Millipore, Billerica, MA, USA) for $1 \mathrm{~h}$. The signal was collected in a Bio-Rad Fluor-S Max detection system and quantified by densitometry analysis using Quantity One software (Bio-Rad, Hercules, CA, USA).

Statistical analysis. Data were expressed as the means \pm SD. Statistical differences between groups were determined by one-way ANOVA followed by the LSD post-hoc test. $\mathrm{P}<0.05$ was considered to be statistically significant.

\section{Results}

Identification of GIRK1-4 subunit mRNAs in human esophageal SMCs. PCR primers were designed to amplify sequences specific for GIRK1-4 subunits. mRNA expression of GIRK subunits was found in human esophageal SMCs in LM and CM layers. Transcripts for GIRK2-4 subunits were identified 
A

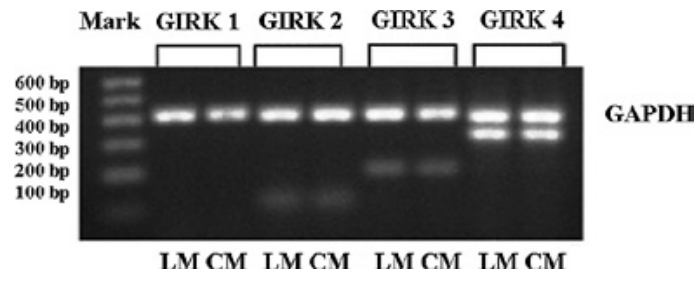

B

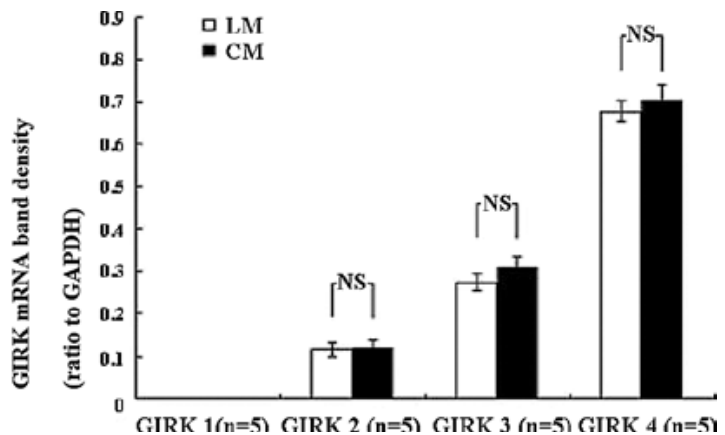

Figure 1. RT-PCR identifies mRNA for GIRKs in both LM and CM layers. (A) PCR products of the expected sizes were obtained as follows: GIRK2, 122 bp; GIRK3, 203 bp; GIRK4, 330 bp and GAPDH, 414 bp. The identity of the products was confirmed by sequencing, ladder and molecular weight markers. (B) The expression of GIRK2 and 3 subunits was significantly less $(\mathrm{P}<0.05)$. No difference was found between the GIRK2 and 3 subunits $(\mathrm{P}>0.05)$. No significant difference was noted between LM and CM layers $(\mathrm{P}>0.05)$.

A

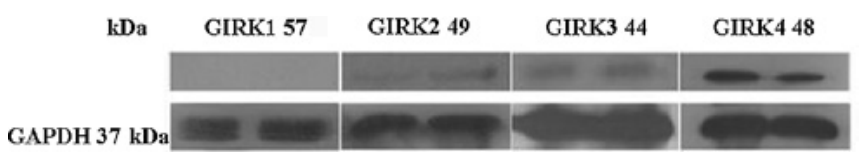

B

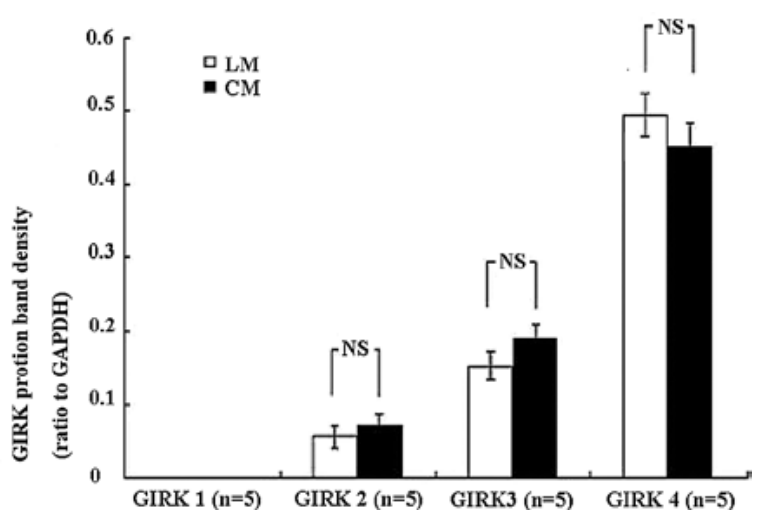

Figure 2. Protein corresponding to GIRKs subunit identified in human esophageal SMCs. (A) Subunit selective antibodies bound to specific protein bands in the LM and CM layers. GIRK1 was not expressed in either LM or CM. GIRK2 expression was shown at the correct molecular weight (49 kDa) in LM and CM. GIRK 3 expression was shown at the correct molecular weight (44 kDa) in LM and CM. GIRK 4 expression was shown at the correct molecular weight (48 kDa) in both of the LM and CM. GAPDH protein was detected at the correct molecular weight (37 kDa) in both of the LM and CM. (B) Compared with the expression of GIRK4 subunit protein, the expression of GIRK2 and 3 subunits was significantly lower (P<0.05). No difference was found between the GIRK2 and 3 subunits $(\mathrm{P}>0.05)$. The expression of GIRK2-4 subunits protein was not significantly different ( $>0.05)$ between human esophageal LM and CM layers.

in cells from both human esophageal LM and CM layers (Fig. 1A). GIRK1 was not expressed in human esophageal SMCs or LM or CM layers (Fig. 1A). The identity of the amplified products was confirmed by direct DNA sequencing.

Compared with the GAPDH group, the mRNA expression of GIRK2-4 subunits in the human LM layer was 0.116 \pm 0.017 , $0.273 \pm 0.025$ and $0.678 \pm 0.031$ for GIRK2, GIRK3 and GIRK4, respectively. The mRNA expression of GIRK2-4 subunits in the human esophageal CM layer was 0.120 \pm 0.0135 , $0.308 \pm 0.031$ and $0.703 \pm 0.037$, respectively (Fig. 1B).

Compared with the expression of GIRK4 subunit mRNA, the expression of GIRK2-3 subunits was significantly lower $(\mathrm{P}<0.05$, Fig. 1B). However, no difference was found between mRNA expression of GIRK2-3 subunits ( $>>0.05$, Fig. 1B). In addition, mRNA expression of GIRK2-4 subunits was not significantly different between human esophageal LM and CM layers ( $\mathrm{P}>0.05$, Fig. 1B).

Identification of GIRK1-4 subunit protein in human esophageal SMCs. To further investigate the expression of the GIRK subunit protein in human esophageal SMCs, the protein expression of GIRK1-4 subunits was determined by immunoblot analysis in human esophageal SMCs.

Specific polyclonal antibodies directed at each GIRK1-4 subunit were used to examine their expression in human esophageal LM and CM SMCs (Fig. 2A). Immunoreactive protein bands corresponding to each were identified and their molecular weights were estimated to be: GIRK1, 57; GIRK2, 49; GIRK3, 44; GIRK4, 48 and GAPDH, 37. Following isolation of the enriched membrane protein using a Bio-Rad kit, the protein expression of GIRK2-4 was determined (Fig. 2A). However, the GIRK1 protein expression was not observed in human esophageal SMCs (Fig. 2A). Signal was collected in a Bio-Rad Fluor-S Max detection system and quantified by densitometry analysis using Quantity One software (Bio-Rad).

Similarly, total protein expression of GIRK2-4 subunits in human esophageal LM layer was $0.056 \pm 0.007,0.153 \pm 0.019$ and $0.495 \pm 0.029$, respectively. Protein expression of GIRK2-4 subunits in human esophageal CM layer was $0.070 \pm 0.0085$, $0.188 \pm 0.028$ and $0.495 \pm 0.029$, respectively (Fig. 2 B).

Compared with the expression of GIRK4 subunit protein, the expression of GIRK2-3 subunits was significantly lower 
$(\mathrm{P}<0.05$, Fig. 2B). However, no difference was found between protein expression of GIRK2-3 subunits ( $\mathrm{P}>0.05$, Fig. $2 \mathrm{~B}$ ). In addition, expression of the GIRK2-4 subunit protein was not significantly different between human esophageal LM and CM layers ( $\mathrm{P}>0.05$, Fig. 2B).

\section{Discussion}

Identification of GIRK2-4 subunits in human SMCs. GIRK channels or acetylcholine-sensitive potassium channels are constructed by the GIRK family including GIRK1-4 subunits (11-13). GIRK subunits are expressed in various tissues. GIRK1-3 subunits are expressed in various regions of the CNS, such as the olfactory bulb, cerebral cortex, amygdala, hippocampus, thalamus, cerebellum, substantia nigra, ventral tegmental region, locus coeruleus, and certain nuclei of the brainstem and spinal cord (14-17), indicating their potential involvement in various CNS functions such as cognition, memory, emotions and motor coordination. In contrast, GIRK4 subunits are expressed in only a few regions of the brain $(15,17,18)$. Neuronal GIRK channels are predominantly heteromultimers comprising of GIRK1-2 subunits in the majority of brain regions $(16,19)$ or homomultimers comprising of GIRK2 subunits in the substantia nigra (20). GIRK1 subunits do not form functional homomeric channels $(5,21)$. In the heart, atrial GIRK channels are predominantly heteromultimers constituting of GIRK1 and 4 subunits (21). However, whether GIRK channels exist in esophageal SMCs remains to be determined.

In this study, our data revealed mRNA expression of GIRK2-4 subunits using the PCR technique, indicating functional GIRK channels existing in human esophageal SMCs. The PCR technique is a more sensitive test, since it amplifies cDNA derived from low-abundance mRNAs. However, the presence of GIRK mRNA in the human esophagus does not prove that the GIRK protein is present in human esophageal SMCs. For this reason, the protein expression of GIRK subunits in human esophageal SMCs was examined using Western blot analysis. Similarly, total protein expression of GIRK2-4 subunits was detected in human esophageal SMCs.

Neither mRNA nor total protein expression of GIRK1 were detected in human esophageal SMCs. In addition, neither mRNA nor total protein expression of GIRK2-4 subunits were significantly different in human esophageal LM and CM layers. Our data indicated that the GIRK2-4 subunits were coexpressed in human esophageal SMCs, and that GIRK4 subunit was the predominant subunit among human esophageal SMCs. Our results indicate a potential role for GIRK channels in the control and modulation of human esophageal SMC functions. Further study is required to determine whether or not the GIRK channels were comprised GIRK2-4 and/or GIRK3-4 heteromers in the human esophagus.

Pathophysiological significance of GIRK channels in the esophagus. Gastro-esophageal reflux disease (GERD) refers to the reflux of gastric contents into the esophagus leading to esophagitis, reflux symptoms sufficient to impair quality of life or long-term complications. Transient relaxation of the lower esophageal sphincter is believed to be the primary mechanism of the disease, although the underlying cause remains to be elucidated (22). ACh stimulates muscle leading to an increased force of contraction and an increased rate of smooth muscle motility via M2 and M3 receptors on the SMC surface $(23,24)$. $\mathrm{ACh}$ is able to depolarize the membrane of SMCs mediated by the $\mathrm{M} 2$ receptor $(25,26)$.

First, the M2 receptor couples to the Gi/Go-type G proteins and stimulates phosphoinositide metabolism, which is linked to $\mathrm{Ca}^{2+}$-signaling events. Intracellular events lead to the depolarization and activation of L-type $\mathrm{Ca}^{2+}$ channels (27), resulting in smooth-muscle contraction (28). Second, M2 receptor stimulation indirectly induces a contraction by inhibiting the adenylyl cyclase and protein kinase A (PKA), which would otherwise have an excitatory effect due to the stimulatory effect of PKA on a number of $\mathrm{K}^{+}$channels in SMCs (29). Third, M2 receptor also inhibits potassium channels and opens non-specific cation channels to induce contraction (30). Under physiological ionic conditions, the muscarinic receptor-mediated current is carried with a reversal potential between -10 and $0 \mathrm{mV}$, whereby depolarization is produced; thus, the discharge of action and slow-wave potentials initiates or accelerates unless the depolarization is extremely strong $(31,32)$. Previous studies have shown that ACh activates and modulates the activity of GIRK channels in esophageal SMCs $(33,34)$.

In addition, the possibility of a basally active $I_{K, A c h}$-like conductance contributes to resting membrane potential along with the activity of GIRK channels (35). In brief, GIRK channels play a significant role in the control and modulation of esophageal SMC function. Our data showed that M2 receptor was down-regulated in the esophagus in acid-perfused rabbits (unpublished data), indicating that GIRK channels may undergo plastic changes under pathological conditions. Further studies are required to explore the molecular basis of the GIRKs in esophageal SMCs and to elucidate their regulatory mechanisms under physiological and pathological conditions.

In conclusion, our study provides evidence that mRNA and the protein expression of GIRK2-4 subunits were present in human esophageal LM and CM cells, whereas GIRK1 was not. GIRK channels in the human esophagus may be potential therapeutic targets in GERD treatment.

\section{References}

1. Doupnik CA, Davidson N and Lester HA: The inward rectifier potassium channel family. Curr Opin Neurobiol 5: 268-77, 1995.

2. Reimann $\mathrm{F}$ and Ashcroft $\mathrm{FM}$ : Inwardly rectifying potassium channels. Curr Opin Cell Biol 11: 503-508, 1999.

3. Ikeda K, Kobayashi T, Kumanishi T, Yano R, Sora I and Niki H: Molecular mechanisms of analgesia induced by opioids and ethanol: is the GIRK channel one of the keys? Neurosci Res 44: 121-131, 2002.

4. Blednov YA, Stoffel M, Alva H and Harris RA: A pervasive mechanism for analgesia: activation of GIRK2 channels. Proc Natl Acad Sci USA 100: 277-282, 2003.

5. Yamada M, Inanobe A and Kurachi Y: G protein regulation of potassium ion channels. Pharmacol Rev 50: 723-760, 1998.

6. Kobayashi T and Ikeda K: G protein-activated inwardly rectifying potassium channels as potential therapeutic targets. Curr Pharm Des 12: 4513-4523, 2006.

7. Kennedy ME, Nemec J, Corey S, Wickman K and Clapham DE: GIRK4 confers appropriate processing and cell surface localization to $\mathrm{G}$ protein-gated potassium channels. J Biol Chem 274: 2571-2582, 1999.

8. Bradley KK, Hatton WJ, Mason HS, et al: Kir3.1/3.2 encodes an $\mathrm{I}(\mathrm{KACh})$-like current in gastrointestinal myocytes. Am J Physiol Gastrointest Liver Physiol 278: G289-G296, 2000. 
9. Uchiyama $\mathrm{T}$ and Chess-Williams R: Muscarinic receptor subtypes of the bladder and gastrointestinal tract. J Smooth Muscle Res 40: 237-247, 2004

10. Tugay M, Yildiz F and Guvenc BH: Development changes esophageal smooth muscle reactivity: an in vitro study. Pharmacol Res 48: 473-478, 2003.

11. Stringer BK, Cooper AG and Shepard SB: Overexpression of the $G$ protein inwardly rectifying potassium channel 1 (GIRK1) in primary breast carcinomas correlates with axillary lymph node metastasis. Cancer Res 61: 582-588, 2001.

12. Mullner C, Vorobiov D, Bera AK, et al: Heterologous facilitation of $\mathrm{G}$ protein-activated $\mathrm{K}(+)$ channels by beta-adrenergic stimulation via cAMP-dependent protein kinase. J Gen Physiol 115 547-558, 2000

13. Bender K, Wellner-Kienitz MC, Inanobe A, Meyer T, Kurachi Y and Pott L: Overexpression of monomeric and multimeric GIRK4 subunits in rat atrial myocytes removes fast desensitization and reduces inward rectification of muscarinic $\mathrm{K}(+)$ current $(\mathrm{I}(\mathrm{K}(\mathrm{ACh})))$. Evidence for functional homomeric GIRK4 channels. J Biol Chem 276: 28873-28880, 2001.

14. Kobayashi T, Ikeda K, Ichikawa T, Abe S, Ogashi S and Kumanishi T: Molecular cloning of a mouse $\mathrm{G}$ protein-activated $\mathrm{K}+$ channel (mGIRK1) and distinct distributions of three GIRK (GIRK1, 2 and 3) mRNAs in mouse brain. Biochem Biophys Res Commun 208: 1166-1173, 1995.

15. Karschin C, Dissmann E, Stuhmer W and Karschin A: IRK(1-3) and GIRK(1-4) inwardly rectifying $\mathrm{K}+$ channel mRNAs are differentially expressed in the adult rat brain. J Neurosci 16 : 3559-3570, 1996

16. Liao YJ, Jan YN and Jan LY: Heteromultimerization of $\mathrm{G}$ protein-gated inwardly rectifying $\mathrm{K}+$ channel proteins GIRK1 and GIRK2 and their altered expression in weaver brain. J Neurosci 16: 7137-7150, 1996.

17. Murer G, Adelbrecht C, Lauritzen I, et al: An immunocytochemical study on the distribution of two $G$ protein-gated inward rectifier potassium channels (GIRK2 and GIRK4) in the adult rat brain. Neuroscience 80: 345-357, 1997.

18. Wickman K, Karschin C, Karschin A, Picciotto MR and Clapham DE: Brain localization and behavioral impact of the $\mathrm{G}$ protein-gated $\mathrm{K}+$ channel subunit GIRK4. J Neurosci 20: 5608-5615, 2000.

19. Lesage F, Guillemare E, Fink M, et al: Molecular properties of neuronal $\mathrm{G}$ protein-activated inwardly rectifying $\mathrm{K}+$ channels. J Biol Chem 270: 28660-28667, 1995.

20. Inanobe A, Yoshimoto Y, Horio Y, et al: Characterization of $\mathrm{G}$ protein-gated $\mathrm{K}+$ channels composed of Kir3.2 subunits in dopaminergic neurons of the substantia nigra. J Neurosci 19 : 1006-1017. 1999
21. Krapivinsky G, Gordon EA, Wickman K, Velimirovic B, Krapivinsky L and Clapham DE: The G protein-gated atrial $\mathrm{K}+$ channel IKACh is a heteromultimer of two inwardly rectifying $\mathrm{K}(+)$-channel proteins. Nature 374: 135-141, 1995.

22. Moayyedi P and Talley NJ: Gastro-oesophageal reflux disease. Lancet 367: 2086-2100, 2006.

23. Diamant NE: Physiology of esophageal motor function. Gastroenterol Clin North Am 18: 179-194, 1989.

24. Zhang LB and Buxton IL: Muscarinic receptors in canine colonic circular smooth muscle. II. Signal transduction pathways. Mol Pharmacol 40: 952-959, 1991.

25. Eglen RM, Hegde SS and Watson N: Muscarinic receptor subtypes and smooth muscle function. Pharmacol Rev 48: 531-565, 1996.

26. Nelson MT, Patlak JB, Worley JF and Standen NB: Calcium channels, potassium channels, and voltage dependence of arterial smooth muscle tone. Am J Physiol 259: 3-18, 1990.

27. Lee HK, Shuttleworth CW and Sanders KM: Tachykinins activate nonselective cation currents in canine colonic myocytes. Am J Physiol 269: 1394-1401, 1995.

28. Sawyer GW and Ehlert FJ. Contractile roles of the M2 and M3 muscarinic receptors in the guinea pig colon. J Pharmacol Exp Ther 284: 269-277, 1998.

29. Sakamoto T, Unno T, Kitazawa $\mathrm{T}$, et al: Three distinct muscarinic signalling pathways for cationic channel activation in mouse gut smooth muscle cells. J Physiol 582: 41-61, 2007.

30. Wickman KD, Iniguez-Lluhl JA, Davenport PA, et al: Recombinant $G$ protein beta gamma-subunits activate the muscarinic-gated atrial potassium channel. Nature 368: 255-257, 1994.

31. So I and Kim KW: Nonselective cation channels activated by the stimulation of muscarinic receptors in mammalian gastric smooth muscle. J Smooth Muscle Res 39: 231-247, 2003.

32. Unno $\mathrm{T}$, Kwon SC, Okamoto $\mathrm{H}$, et al: Receptor signaling mechanisms underlying muscarinic agonist-evoked contraction in guinea-pig ileal longitudinal smooth muscle. Br J Pharmacol 139: 337-350, 2003.

33. Dobrzynski H, Janvier NC, Leach R, Findlay JB and Boyett MR Effects of ACh and adenosine mediated by Kir3.1 and Kir3.4 on ferret ventricular cells. Am J Physiol Heart Circ Physiol 283: 615-630, 2002

34. Nikolov EN and Ivanova-Nikolova TT: Dynamic integration of alpha-adrenergic and cholinergic signals in the atria: role of $\mathrm{G}$ protein-regulated inwardly rectifying $\mathrm{K}+$ channels. J Biol Chem 282: 28669-28682, 2007.

35. Flynn ER, McManus CA, Bradley KK, et al: Inward rectifier potassium conductance regulates membrane potential of canine colonic smooth muscle. J Physiol 518 : 247-256, 1999. 